\title{
Impact of Changing Management on Hotels' Employees
}

\author{
Mohamed A. Ali ${ }^{\mathrm{a}}$, Ahmed N. Elias ${ }^{\mathrm{b}}$, Reham D. Toni ${ }^{\mathrm{a}}$ \\ ${ }^{a}$ Hotel Studies Department, Faculty of Tourism and Hotels, Minia University \\ ${ }^{\mathrm{b}}$ Hotel Management Department, Faculty of Tourism and Hotel Management, Helwan University
}

\begin{abstract}
This paper examines the effect of changing management on employees in Egyptian hotels. A quantitative method is used to collect the required data. The sample consisted of 5 hotels; all of these hotels changed the management company to another one. The research was conducted by surveying 46 employees of food and beverage employees in these hotels. The researchers tested four hypotheses to identify the impact of changing process on the employees' satisfaction, the relations between employees, employees' loyalty, and the employees' performance. SPSS V. 15.0 is used to analyze data, and statistical analysis included Cronbach's alpha and multiple regression analysis. Empirical findings showed that psychological support and equality between the employees have an influence significantly on employees' satisfaction, equality and change of job behaviour have an influence significantly on the relations between employees, Equality and psychological support have an influence significantly on employees' loyalty, and change of job behaviour and equality between the employees have an influence significantly on the employees' performance.
\end{abstract}

Keywords: Changing Management, Equality between the Employees, Psychological Support, Job Behaviour, Employees' Loyalty.

\section{Introduction}

Building a new culture is an important job. Culture changing may be performed through using new role models, focusing on basic business values, changing the structure, changing the reward system, and the best cultures are developed when a consistent approach is used $^{(1)}$. Changing management has an effect on employees' turnover, performance, job satisfaction, relations, and the psychological state of them, so the new management must treat with this problems avoiding negative effects of this change, the new management may use methods such as hiring change agent ${ }^{(2)}$.

"Cultural change is more about addressing what is beneath the surface and may be harder to change than about addressing broad strategic direction, or changing tactics. Cultural change is seen and experienced as something much deeper that cannot be wholly designed or implemented but needs to grow from within" ${ }^{(3)}$.

Changing processes failed in organization because of the misunderstanding of culture and climate within the organization. Culture refers to a deep rooted values and traditions, while climate is its current practices. On the other hand, successful changing process depends on adopting networked systems, and enhanced communication and cooperation $^{(4)}$. Successful adaptation to new culture requires that employee must understand the new culture and motivate them to adapt this culture ${ }^{(5)}$. To make successful change it must be begin with results, the true purpose is to achieve particular ends or outcomes beside short term gains ${ }^{(6)}$. 


\section{Organizational Culture}

Every organization has a culture, which consists of the core values and beliefs shared by the employees of the organization ${ }^{(7)}$. Organizational culture refers to "a system of shared meaning held by members distinguishing the organization from other organizations" ${ }^{(8)}$. The organizational culture is defined as "the set of key values, beliefs, understandings, and norms shared by members of an organization" ${ }^{(9)}$.

Innovation and risk taking, Attention to detail, Outcome orientation, People orientation, Team orientation, Aggressiveness, and Stability are the seven characteristics that make the core of an organization's culture ${ }^{(10)}$. "The organizational culture existed on two levels, the observable and unobservable. The observable elements referred to the physical characteristics of the organization, including: behavior, rules, rituals and ceremonies, myths, stories, dress, general appearance and language. The unobservable elements of organizational culture included: norms, assumptions, beliefs, ideology, values and perceptions of the organization" ${ }^{(11)}$.

\subsection{Values}

Values are standards of merit, which tell individual what is worthy of desire and what isn't, what is moral or ethical and what is not, what is appropriate and what isn't, values are acquired through experience, instruction, and rational thought, with the foundation returned to early childhood ${ }^{(7)}$. Values have both content and intensity, the content attribute declares that a mode of conduct or end-state of existence is important. The intensity attribute specifies how important it is. People in the same occupations tend to hold similar values ${ }^{(12)}$.

Corporate values are defined as "a set of principles that guide and define how a company should treat its employees, shareholders, and customers"(13). Corporate values should remain unbroken in spite of changes of business or economy, be applicable to everybody in the establishment, be applied time after time regardless of issues, and remain stable regardless of employees' management changes ${ }^{(14)}$.

Societies and organizations shape values, and there are many persons in the individual life play an important role in shaping their values development by providing guidance about what is right and good ${ }^{(15)}$. The manipulation of myths and symbols, can often lead to value change, value change is hardly an exact science - even when done under pressure, when behavioral acquiescence will often mask aggressive or hesitant feelings ${ }^{(16)}$.

The Rokeach Value Survey (RVS) distinguished between two sets of values terminal and instrumental as follows:

- Instrumental values: reflect a person's beliefs about the means for achieving desired goals; include ambition, honesty, self-sufficiency, and courage.

- Terminal values: values that represent the goals to be achieved or the end state of existence include happiness, love, pleasure, self-respect, and freedom ${ }^{(17)}$. 


\subsection{Attitudes}

The attitude is defined as "providing a state of readiness or tendency to respond in a particular way"(18). Attitudes are linked with perception, personality, and motivation. So, they are determinants of behavior. The attitude may be positive or negative feeling or mental state of readiness, learned and organized through experience. It influences on a person's response to many things such as people, objects, and situations ${ }^{(19)}$.

There are three types of attitudes at organizations:

- Job satisfaction: refers to a collection of feelings that an individual holds towards his or her job.

- Job involvement: measures the degree to which the person identifies psychologically with his or her job and considers his or her perceived performance level important to self-worth.

- Organizational commitment: defined as a state in which an employee identifies with a particular organization and its goals, and wishes ${ }^{(12)}$.

Attitudes could be understood better by recognizing that every attitude has three distinct components, which are cognitive, affective and behavioral tendencies. Each of this type of attitude toward change may induce a person to support or not changes occurring in an organizational setting. Attitudes can be difficult to change once they have been learned ${ }^{(20)}$. The process of attitude change is dependent on a number of key factors including; why an attitude is held in the first place, why it should change, what the benefits are and for whom; and the likely outcomes if it doesn't change ${ }^{(18)}$.

\subsection{Beliefs}

Beliefs are representing ideas about someone or something and the conclusions which people draw about them ${ }^{(21)}$. Beliefs are defined as "rules acquired through experience, instruction, or rational thought". Beliefs are notions about how things work and what the result will be if the person does this or that. So, every employee need to understand his organization's and his unit's cultures because they influences his boss's, himself, his employees, expectations, decisions, and actions if employee understand this and why people in his work do this it helps to knew about the values and beliefs that motivate them $^{(7)}$.

\subsection{Organizational Change}

The theory and practice of organizational change and development are linked to employees' understandings of organizational culture. There are a variety of perspectives on the concept of organizational culture ${ }^{(22)}$.

Organizational change can also be examined as a process, steps to move from an organization's current state towards a desired future state can generally be described as a three-part process as the following ${ }^{(23)}$ :

A- Planning change:

i. The idea and its context

ii. Define the change initiative 
iii. Evaluate the climate of change

iv. Develop a change plan

B- Implementing Change:

i. Find and Cultivate a sponsor

ii. Prepare for the target audience, the recipients of change

iii. Create the culture fit- making the change last

iv. Develop and Choose a change leader team

C- Managing Change:

i. Create small wins for motivation

ii. Constantly and Strategically communicate the change

iii. Measure progress of the change effort

iv. Integrate lessons learned.

The risk of failure is greater as employees are generally resistant to changes. For some employees, change may bring satisfaction, joy and advantages, while for other employees the same change may bring pain, stress and disadvantages ${ }^{(20)}$.

\subsection{Employees Reactions to Change}

People fear the unknown; they find change difficult and don't like it ${ }^{(24)}$. So, much of this literature has focused on negative emotions such as anxiety, nervousness, aggression, and hostility $^{(3,25)}$. Employees' reactions to change are frustration and anger, some of these employees expressed that they experienced stress and physical and psychological problems, and this change may affect the health of employees. Other reactions may relate to the job like job dissatisfaction, less of motivation, and uncertainty about their job ${ }^{(26)}$. Organizational changes act as a source of stress for the employees and feelings of uncertainty. Uncertainty in the organizational environment can lead to the fear of job loss among employees. On the other hands, the organizational change may be welcomed in certain cases where employees are prepared to deal with the changing situation ${ }^{(27)}$.

Employees' attitudes toward change are a key component to whether an organization's change efforts are either successful or failed. When employees possess a strong, positive attitude toward change, they are likely to behave in supportive manners with the change. Moreover, when employees possess a strong, negative attitude toward change, they are more likely to resist ${ }^{(28)}$.

"Often it is not the change itself which leads to negative affect and subsequent behaviours of withdrawal, aggressive reactions, resignation, sabotage, etc. It is how change and, these days, how continuous and large-scale change are managed"(29). Employees go through a reaction process when they are personally confronted with major organizational change, this process consists of four stages; initial denial, resistance, gradual exploration and eventual commitment ${ }^{(30)}$. Individuals do not always experience these changes in a uniform or same way; employees are different ${ }^{(31)}$.

\subsection{Resistance to Change}

Resistance to change is defined as "a phenomenon that affects the changing process, delaying or slowing down its beginning, obstructing or hindering its implementation, and increasing its costs" ${ }^{(32)}$. Resistance to change is "any attitude or behavior that indicates 
unwillingness to make or support a desired change" ${ }^{(21)}$. Resistance to change is the more common reaction ${ }^{(33)}$. It is normal and to be expected in any change effort. Resistance to change takes many forms ${ }^{(31)}$. Resistance to change is typical in organizations whenever a new initiative is undertaken. Resistance to change is weakest during crisis conditions and therefore stronger when conditions fall short of crisis $^{(3)}$.

Resistance to change is "significantly associated with employees' job satisfaction, organizational commitment, and intention to leave the organization, which are all important to the success of organizational change" ${ }^{(34)}$. "Resistance to change can be traced back to eight reasons: 1) fear of the unknown; 2) lack of pertinent information; 3) fear of losing knowledge; 4) a change that is perceived as or is really useless; 5) fear of losing control/power; 6) a lack of resource; 7) poor timing; and 8) an attachment to habits" ${ }^{\prime(35)}$. Employees don't resist change but they resist the loss of status, loss of pay, or loss of comfort. In other words, employees don't resist the change but they resist consequences of change ${ }^{(26)}$.

The main reasons of resistance to change in hotels as: financial difficulties; cost of change; lack of resources; fear of losing the existing customer; time limitation; priority of other businesses; lack of cooperation and skills; fear of insecurity; losing something valuable; and internal politics ${ }^{(18)}$.

The management can overcome employees' resistance to change through many techniques such as effective communication of the justifications behind the changes or involvement strategies, and clear leadership ${ }^{(24)}$. Solutions for every reason of resistance may be as follows: low tolerance of change can often be overcome with supportive, patient supervision. If politics and self interest are at the root of resistance, it might be possible to face the resistance by giving resistors a special desirable role in the changing process or by negotiating special incentives for change. If misunderstandings, lack of trust, or different assessments, good communication can be a good solution. Involving the people who are the targets of change in the changing process usually reduces their resistance $^{(36)}$.

\subsection{Change Agent}

The success of implementing change is generally associated with those who facilitate the changing process. The change agent is defined here as "a manager who seeks to reconfigure an organization's roles, responsibilities, structures, outputs, processes, systems, technology or other resources" ${ }^{(2)}$. Change agents are the people who lead and support the changing processes. Although change agents sometimes are hired as consultants from outside the organization, it is also true that managers, team leaders, and others working in firms are expected to act as change agents ${ }^{(37)}$. Most researchers attribute a great deal of success of organizational changes to the effectiveness of the person responsible for the change, who is usually referred to as the change agent ${ }^{(1)}$.

\subsection{The Manager's Role during Change}

The middle managers play an essential role in major culture change ${ }^{(38)}$. There are six steps in sequential order in management of change as the following ${ }^{(1)}$ :

1- Diagnose the present condition, including the need for change. 
2- Set goals and defines the new state or condition after the change.

3- Define the transition state between the present and the future.

4- Develop strategies and action plans for managing the transition.

5- Evaluate the change effort.

6- Stabilize the new condition and establish a balance between stability and flexibility.

Managers must be responsive to change. Management must take into consideration the importance of human and social factors of change. So, management role in changing management is as follows ${ }^{(18)}$ :

- Create an environment of trust and shared commitment, and involve staff fully in decisions and actions which affect them;

- Maintain full and open communications, and the genuine participation of all staff concerned, preferably well before the actual introduction of the change;

- Emphasize benefits of the change, and potential opportunities presented by it;

- Encourage team management and a cooperative spirit among staff;

- Give attention to job design, methods of work organization and the development of cohesive groups;

- Provides suitable economic incentive schemes to safeguard potential loss of earnings or job security, and ensure an equitable allocation of any financial savings resulting from the change;

- Design a personal management action programme directed to a review of recruitment and selection.

\subsection{Change and Psychological Aspects}

The employees make unconscious process (resistance) as defense mechanisms in response to the perceptions of the danger as a result to the change of management. The employees adopt these mechanisms to lessen worry ${ }^{(30)}$. The concept of the psychological contract could be understood as individual beliefs regarding the terms and conditions of a mutual agreement between the individual and the organization. A psychological contract may differ from the formal, written legal contract but is very real to the persons who hold them ${ }^{(39)}$.

\subsection{Change and Job Satisfaction}

Job satisfaction is "an emotional state resulting from the evaluation or appraisal of one's job experiences" ${ }^{(40)}$. Job satisfaction is a function of the perceived relationship between what employees want from his job and what this employee perceives it as offering, there is a relationship between job satisfaction and organizational commitment and a relationship between job satisfaction and performance. Employees with higher job satisfaction absent less ${ }^{(41)}$. Organizations want to measure their employees' satisfaction; the organization may need to create its own scales to measure employees' job satisfaction $^{(42)}$. 


\subsection{Change and Performance}

Performance refers to the degree of accomplishment of the tasks that make up an employee's job. It reflects how well an employee is fulfilling the requirements of a job. Performance is measured in terms of results ${ }^{(43)}$. Strategic change management can be a challenging task that requires careful performance measurement before, during and after the process of change. The performance measurement system allows the preliminary definition of financial and non-financial measures to lead design and implementation of strategic changes. This multidimensional performance measurement system can improve the organization's ability to adapt and survive ${ }^{(44)}$.

\subsection{Change and Equal Opportunities}

Equal employment opportunity refers to the management's attempt to ensure that all persons have an equal chance for employment, regardless of race, color, religion, sex, or national origin ${ }^{(42)}$. Equity theory subtracts that employees respond to an inequitable employment relationship in terms of job dissatisfaction, non-compliance or exit. The workers are deeply influenced by an employer's consistency and sensitivity in dealing with issues of fairness, justice and equality ${ }^{(45)}$.

\subsection{Change and the relations between employees}

Many change management interferences are based on the belief that communicating with employees about change will promote cooperation and reduce resistance to change, while also minimizing worry and uncertainty about change ${ }^{(46)}$.

The social exchange perspective, the justice view perspective, the industrial relations perspective, the legal perspective and the economic perspective are five perspectives on the employment relationship and the way in which trust is built ${ }^{(39)}$. Positive actions directed at employees by the organization and/or its representatives contribute to the establishment of high quality exchange relationships, which based on employees trusting that the other parties will meet their obligations in the long run ${ }^{(29)}$. Because human resources are the primary asset of these firms, personal and social relations become of decisive importance ${ }^{(47)}$.

\subsection{Change and Employees' Loyalty}

Loyalty is a complex construct ${ }^{(48)}$. Loyalty is referring to an employee's level of attachment to the organization. Sometimes number of employees despite of felling job insecurity they may also respond by staying loyal to the organization, but it must be known that there is experiential consensus which suggested that loyalty is negatively affected by change and uncertainty ${ }^{(49)}$.

\section{Methodology}

This part presents the adopted methodology to test the proposed hypotheses, the design of the sample, data collection procedures, and the used statistical analysis. 


\subsection{Research Hypotheses}

A number of hypotheses have been tested during the present investigation:

- Hypothesis 1: Changing process influences significantly on the employees' satisfaction

- Hypothesis 2: Changing process influences significantly on the relations between employees

- Hypothesis 3: Changing process influences significantly on employees' loyalty.

- Hypothesis 4: Changing process influences significantly on the employees' performance.

\subsection{Sample of the Research}

The population of this study comprises of hotels which have changed the management company to another one, five hotels between these hotels have accepted to co-operate and respond to this study. These hotels are illustrated in table 1.

Table 1. The investigated hotels

\begin{tabular}{|l|c|c|c|c|}
\hline \multicolumn{1}{|c|}{ Hotel } & City & Classification & $\begin{array}{c}\text { Previous } \\
\text { management } \\
\text { company }\end{array}$ & $\begin{array}{c}\text { Current } \\
\text { management } \\
\text { company }\end{array}$ \\
\hline $\begin{array}{l}\text { Sofitel Cairo El } \\
\text { Gezirah }\end{array}$ & Cairo & 5 star & Sofitel & Sheraton \\
\hline VAL Tours Hotel & Sharm El-Sheik & 5 star & Lewis Tiran & VAL Tours \\
\hline AA Amwaj Hotel & Sharm El-Sheik & 5 star & Millennium & $\begin{array}{c}\text { Accommodations } \\
\text { and Activities }\end{array}$ \\
\hline AA Grand Oasis & Sharm El-Sheik & 4 star & Tropicana & $\begin{array}{c}\text { Accommodations } \\
\text { and Activities }\end{array}$ \\
\hline $\begin{array}{l}\text { Top Choice Viva } \\
\text { Club }\end{array}$ & Sharm El-Sheik & 3 star & Falcon & Top Choice \\
\hline
\end{tabular}

\subsection{Research Tools}

This study is concerned with investigating the impact of change of management on hotels' employees in Egyptian hotels (employees' satisfaction, the relations between employees, employees' loyalty, and employees' performance). So, the questionnaire for food and beverage employees is designed. This questionnaire included 27 statements using a five point likert scale to identify the impact of change of management on hotels' employees.

\subsection{Pilot study}

A pilot study was conducted to ensure that the questions were understandable and specific to study the impact of change of management on hotels'. The pilot study suggested some clarifications to the survey. For Instance, the researchers deleted some statements such as I lost my rights when change occurred, because the respondents of pilot study stated that this statement is not clear. 


\subsection{Data Analysis}

The collected data were analyzed using Statistical Package for Social Sciences (SPSS) version 15.0. Appropriate statistical analyses such as Cronbach's $\alpha$ (alpha) measure and stepwise regression were used to achieve the objectives of this study.

\subsection{Sample}

The questionnaire of this research was distributed to a randomly selected group of food and beverage employees in the hotels which are mentioned in table 1. A total of 79 questionnaires were distributed, $56(70.88 \%)$ questionnaires were returned, and 46 $(58.22 \%)$ questionnaires were valid.

\section{Results}

This part presents the results of data analysis and hypotheses testing results.

\subsection{Assessing Scale Reliability}

To test the reliability, the Cronbach's alpha of the questionnaire was determined. The results showed that the alpha coefficient was 0.877 . The results were considered more than reliable.

Table 2. Reliability analysis

\begin{tabular}{|c|c|}
\hline Cronbach's Alpha & No. of Items \\
\hline 0.877 & 25 \\
\hline
\end{tabular}

\section{Hypothesis 1: Changing process influences significantly on the employees' satisfaction}

The testing of Hypothesis 1 requires the use of multiple regression analysis to examine the interaction of selected variables.

Table 3. Multiple regression results of changing process on employees' satisfaction

\begin{tabular}{|l|c|c|c|c|c|c|c|c|c|c|}
\hline \multicolumn{1}{|c|}{ Statement } & $\mathrm{R}$ & $\mathrm{R}^{2}$ & $\begin{array}{c}\text { Adjusted } \\
\mathrm{R}^{2}\end{array}$ & $\mathrm{~F}$ & Sig. & $\mathrm{T}$ & Sig. & Beta & \multicolumn{2}{|c|}{$\begin{array}{c}\text { Unstandardize } \\
\mathrm{d} \\
\text { coefficient }\end{array}$} \\
\hline Constant & 0.701 & 0.491 & 0.48 & 42.5 & 0.0 & 4.33 & 0.00 & 0.52 & 0.68 & 0.15 \\
$\begin{array}{l}\text { Psychological } \\
\text { support }\end{array}$ & 0.749 & 0.561 & 0.54 & 27.49 & 0.0 & 2.61 & 0.01 & 0.31 & 0.37 & 0.14 \\
$\begin{array}{l}\text { Equality } \\
\text { between the } \\
\text { employees }\end{array}$ & 0.0 .44 & 0.49 \\
\hline
\end{tabular}

To predict the goodness-of-fit of the regression model, the multiple correlation coefficient (R), coefficient of determination (R2), and F ratio were examined. First, the $R$ 
of independent variables (Psychological support, Equality and the equal opportunities) on the dependent variable (employees' satisfaction) is 0.749 , which showed that the employees had positive and high satisfaction levels with the two dimensions. Second, the $\mathrm{R} 2$ is 0.561 , suggesting that more than $56 \%$ of the variation of employees' satisfaction was explained by Psychological support and Equality and the equal opportunities. Last, the $F$ ratio, which explained whether the results of the regression model could have occurred by chance, had a value of $27.49(\mathrm{p}=0.00)$ and was considered significant. The regression model achieved a satisfactory level of goodness-of-fit in predicting the variance of employees' satisfaction in relation to the two factors, as measured by the above - mentioned R, R2, and F ratio. In other words, at least one of the two factors was important in contributing to employees' level of satisfaction with the change management.

In the regression analysis, the beta coefficients could be used to explain the relative importance of the two dimensions (independent variables) in contributing to the variance in employees' satisfaction (dependent variable). As far as the relative importance of the two changing process activities is concerned, Psychological support carried the heaviest weight for employees' satisfaction, followed by Equality and the equal opportunities. The regression equation is as follows:

Employees' satisfaction $=-0.44+0.68$ Psychological support +0.37 Equality and the equal opportunities.

Educating the new style of management and change of job behaviour have no influence significantly on the employees' satisfaction.

\section{Hypothesis 2: Changing process influences significantly on the relations between employees}

To verify this hypothesis, the researchers calculated stepwise regression and multiple correlations between Changing process activities and the relations between employees.

Table 4. Multiple regression results of changing process on the relations between employees

\begin{tabular}{|c|c|c|c|c|c|c|c|c|c|c|}
\hline \multirow[t]{2}{*}{ Statement } & \multirow[t]{2}{*}{$\mathrm{R}$} & \multirow[t]{2}{*}{$\mathrm{R}^{2}$} & \multirow[t]{2}{*}{$\begin{array}{c}\text { Adjust } \\
\text { ed } \\
\mathrm{R}^{2}\end{array}$} & \multirow[t]{2}{*}{$\mathrm{F}$} & \multirow[t]{2}{*}{ Sig. } & \multirow[t]{2}{*}{$\mathrm{T}$} & \multirow[t]{2}{*}{ Sig. } & \multirow[t]{2}{*}{ Beta } & \multicolumn{2}{|c|}{$\begin{array}{c}\text { Unstandardize } \\
\mathrm{d} \\
\text { coefficient } \\
\end{array}$} \\
\hline & & & & & & & & & B & $\begin{array}{l}\text { Std. } \\
\text { error }\end{array}$ \\
\hline Constant & & & & & & -.46 & .64 & & -.024 & 0.51 \\
\hline $\begin{array}{l}\text { Equality between the } \\
\text { employees }\end{array}$ & 0.679 & 0.461 & 0.449 & 37.66 & 0.0 & 5.98 & 0.00 & 0.60 & 0.63 & 0.10 \\
\hline $\begin{array}{l}\text { Change of job } \\
\text { behaviour }\end{array}$ & 0.760 & 0.578 & 0.558 & 29.39 & 0.0 & 3.44 & 0.001 & 0.34 & 0.40 & 0.11 \\
\hline
\end{tabular}

To predict the goodness-of-fit of the regression model, the multiple correlation coefficient (R), coefficient of determination (R2), and F ratio were examined. First, the R of independent variables (Equality and the equal opportunities and Change of job behaviour) on the dependent variable (the relations between employees) is 0.760 , which showed that there was significant positive correlation between the relations between employees (as dependent variable) and the Equality and the equal opportunities and 
change of job behaviour (as independent variables). Second, the R2 is 0.578 , suggesting that more than $57 \%$ of the variation of relations between employees was explained by Equality and change of job behaviour. Last, the F ratio, which explained whether the results of the regression model could have occurred by chance, had a value of 29.39 $(p=0.00)$ and was considered significant. The regression model achieved a satisfactory level of goodness-of-fit in predicting the variance of the relations between employees in relation to equality and change of job behaviour, as measured by the above -mentioned $\mathrm{R}, \mathrm{R} 2$, and $\mathrm{F}$ ratio. In other words, at least one of the two factors was important in contributing to the relations between employees with the change management.

In the regression analysis, the beta coefficients could be used to explain the relative importance of the two dimensions (independent variables) in contributing to the variance in the relations between employees (dependent variable). As far as the relative importance of the two changing process activities is concerned, Equality between the employees carried the heaviest weight for the relations between employees, followed by Change of job behaviour. The regression equation is as the following:

The relations between employees $=-.024+0.63$ Equality and the equal opportunities + 0.40 Change of job behaviour.

Educating the new style of management and psychological support have no influence significantly on the relations between employees.

\section{Hypothesis 3: Changing process influences significantly on employees' loyalty.}

The testing of Hypothesis 1 requires the use of multiple regression analysis to examine the interaction of selected variables.

Table 5. Multiple regression results of changing process on employees' loyalty

\begin{tabular}{|c|c|c|c|c|c|c|c|c|c|c|}
\hline \multirow[t]{2}{*}{ Statement } & \multirow[t]{2}{*}{$\mathrm{R}$} & \multirow[t]{2}{*}{$\mathrm{R}^{2}$} & \multirow{2}{*}{$\begin{array}{c}\text { Adjus } \\
\text { ted } \\
\mathrm{R}^{2}\end{array}$} & \multirow[t]{2}{*}{$\mathrm{F}$} & \multirow[t]{2}{*}{ Sig. } & \multirow[t]{2}{*}{$\mathrm{T}$} & \multirow[t]{2}{*}{ Sig. } & \multirow[t]{2}{*}{ Beta } & \multicolumn{2}{|c|}{$\begin{array}{c}\text { Unstandardized } \\
\text { coefficient }\end{array}$} \\
\hline & & & & & & & & & B & $\begin{array}{l}\text { Std. } \\
\text { error }\end{array}$ \\
\hline Constant & & & & & & -2.28 & 0.27 & & -0.91 & 0.401 \\
\hline $\begin{array}{l}\text { Equality between the } \\
\text { employees }\end{array}$ & 0.784 & 0.615 & 0.606 & 70.34 & 0.0 & 5.90 & 0.0 & 0.54 & 0.68 & 0.115 \\
\hline Psychological support & 0.865 & 0.747 & 0.736 & 63.63 & 0.0 & 4.74 & 0.0 & 0.43 & 0.60 & 0.128 \\
\hline
\end{tabular}

To predict the goodness-of-fit of the regression model, the multiple correlation coefficient (R), coefficient of determination (R2), and F ratio were examined. First, the R of independent variables (Equality and psychological support) on the dependent variable (employees' loyalty) is 0.865 , which showed that the employees had positive and high loyalty with equality and psychological support. Second, the R2 is 0.747 , suggesting that more than $74 \%$ of the variation of employees' loyalty was explained by equality and psychological support. The $\mathrm{F}$ ratio, which declared whether the results of the regression model could have occurred by chance, had a value of $63.63(\mathrm{p}=0.00)$ and was considered significant. The regression model achieved a satisfactory level of goodness-of-fit in predicting the variance of employees' loyalty in relation to equality and psychological support, as measured by the above -mentioned R, R2, and F ratio. As such, at least one of 
the two factors was important in contributing to employees' loyalty with the change management.

In the regression analysis, the beta coefficients could be used to explain the relative importance of the two dimensions (independent variables) in contributing to the variance in employees' loyalty (dependent variable). Insofar as the relative importance of the two changing process activities is concerned, Equality between the employees carried the heaviest weight for employees' loyalty, followed by psychological support. The regression equation is as follows:

Employees' loyalty $=-0.91+0.68$ Equality between the employees +0.60 Psychological support.

Educating the new style of management and change of job behaviour have no influence significantly on employees' loyalty.

\section{Hypothesis 4: Changing process influences significantly on the employees' performance.}

To verify this hypothesis, stepwise regression and multiple correlations have calculated between changing process activities and employees' performance.

Table 6. Multiple regression results of changing process on employees' performance

\begin{tabular}{|l|c|c|c|c|c|c|c|c|c|c|}
\hline \multicolumn{1}{|c|}{ Statement } & $\mathrm{R}$ & $\mathrm{R}^{2}$ & $\begin{array}{c}\text { Adjusted } \\
\mathrm{R}^{2}\end{array}$ & $\mathrm{~F}$ & Sig. & $\mathrm{T}$ & Sig. & \multicolumn{2}{|c|}{$\begin{array}{c}\text { Beta } \\
\text { Unstandardized } \\
\text { coefficient }\end{array}$} \\
\hline Constant & & & & & & & & & & \multicolumn{2}{c}{$\begin{array}{c}\text { Std. } \\
\text { error }\end{array}$} \\
Change of job behaviour & 0.753 & 0.567 & 0.558 & 57.71 & 0.00 & 4.693 & 0.00 & 0.48 & 0.492 & 0.105 \\
$\begin{array}{l}\text { Equality between the } \\
\text { employees }\end{array}$ & 0.839 & 0.704 & 0.691 & 51.21 & 0.00 & 4.462 & 0.00 & 0.45 & 0.501 & 0.112 \\
\hline
\end{tabular}

To predict the goodness-of-fit of the regression model, the multiple correlation coefficient (R), coefficient of determination (R2), and F ratio were examined. First, the R of change of job behaviour and Equality between the employees as independent variables on the employees' performance as dependent variable is 0.839 , which showed that the employees had positive and high performance with change of job behaviour and equality between the employees. Second, the R2 is 0.704 , suggesting that more than $70 \%$ of the variation of employees' performance was explained by change of job behaviour and equality between the employees. The $\mathrm{F}$ ratio, which declared whether the results of the regression model could have occurred by chance, had a value of $51.21(\mathrm{p}=0.00)$ and was considered significant. The regression model achieved a satisfactory level of goodnessof-fit in predicting the variance of employees' performance in relation to the two dimensions, as measured by the above - mentioned $\mathrm{R}, \mathrm{R} 2$, and $\mathrm{F}$ ratio. As such, at least one of the two factors was important in contributing to employees' performance with the change management. 
In the regression analysis, the beta coefficients could be used to explain the relative importance of change of job behaviour and equality between the employees (independent variables) in contributing to the variance in employees' performance (dependent variable). As far as the relative importance of the two changing process activities is concerned, change of job behaviour carried the heaviest weight for employees' performance, followed by equality between the employees. The regression equation is as the following:

Employees' performance $=-0.159+0.492$ Change of job behaviour +0.501 Equality between the employees.

Educating the new style of management and psychological support have no significant influence on employees' performance.

\section{Discussion}

The purpose of this study was to test the effect of changing management companies on hotels' employees. The researchers predicted that changing process activities influence significantly on employees' satisfaction, the relations between employees, employees' loyalty, and employees' performance. The findings of this research declared that psychological support and equality between the employees have an influence significantly on employees' satisfaction, equality and change of job behaviour have an influence significantly on the relations between employees, Equality and psychological support have an influence significantly on employees' loyalty, and change of job behaviour and equality between the employees have an influence significantly on the employees' performance.

Equality between the employees has a crucial role in the success of change management process, whereas the equality between the employees has an influence significantly on employees' satisfaction, the relations between employees, employees' loyalty, and employees' performance.

The significance of equality in the workplace was seen as vital by all organizations ${ }^{(50)}$. Equality and the equal opportunities between the employees could make a difference in the workplace ${ }^{(51)}$. As well as, employees' performance during change increased when they feel justice and trust ${ }^{(29)}$.

When an organization acts in a way that is perceived to be unfair or unjust, then an adjustment is likely to take place in respect of the injured party's level of commitment to meeting the employer's expectations. If the unfairness is perceived to be systemic then all employees will adjust their conception to be the existing psychological contract and its behaviour and expectations will change accordingly ${ }^{(4)}$.

The psychological impact of change on employees is effective. So, some employees preferred retirement rather than dealing with this new change ${ }^{(52)}$. Uncertain, ambiguous, or uncontrollable situations lead to decreases in job satisfaction ${ }^{(53)}$. Moreover, Employees with higher job satisfaction absent less ${ }^{(41)}$. So, job satisfaction is important indicator for employees' adjustment to organizational change. Changes are negatively associated with job satisfaction and positively related to intentions to leave an organization ${ }^{(46)}$.

Employees feel ill by the prospect of change, viewing it as a threat to their relationship at work, their financial security and their daily routine. The negative attitudes towards 
change are generally due to the perception of a lack of control over the stressful situation $^{(27)}$. Despite number of employees have a feeling of job insecurity, they may also respond by staying loyal to the organization, but it must be known that there is experiential consensus which suggested that loyalty is negatively affected by change and uncertainty ${ }^{(49)}$.

In terms of study limitations, the study concentrates on food and beverage employees only. There are many other departments in the hotels. However, further research should examine the effect of changing management on hotels' Employees of other departments.

\section{Recommendations}

Based on the literature reviewed, field study, and findings, the following recommendations could be suggested:

1. The new management should take into consideration employees because they are the foundation of the success or failure of the hotel, and take care about cultural differences between employees.

2. Involving the employees in decision making is a vital aspect, as well as following a scientific method to overcome employees' resistance to change.

3. The new management should organize programs for employees to inform them about the new administrative thoughts.

4. It is worth to gain the trust of employees and create an atmosphere of harmony between the management and the employees and between employees themselves.

5. The new management should make employees has a sense of job security and equality as a result of this change, because a sense of job insecurity and inequality affect negatively and significantly on performance levels. 


\section{References}

1- Anderson, C.R. (1984). Management Skills, Functions, and Organization Performance. $1^{\text {st }}$ ed., Brown Publishers, Dallas, Texas, pp. 447 - 464.

2- Saka, A. (2003). Internal change agents' view of the management of change problem. Journal of Organizational Change Management, Vol. 16 (5), p. 480 496.

3- By, R. T. and, Macleod, C. (2009). Managing Organizational Change in Public Services. $1^{\text {st }}$ ed., Rouledge Taylor and Francis Group, London, pp. 29- 202.

4- Sopow, E. (2006). The Impact of Culture and Climate on Change. Journal of Strategic Human Resource Review, Vol. 6 (2), pp. 20, 23.

5- Earley, P. C. (2002). Redefining Interactions across Cultures and Organizations: Moving Forward with Cultural Intelligence. Journal of Organizational Behavior, Vol. 24, p. 286.

6- Windsor, D. (2003). Change Management Competencies for Creating Collaborative Organization. Journal of Team Based Organizing, Vol. 9, pp. 3850 .

7- Beach, L.R. (2007). The Human Element-Understanding and Managing Employee Behavior. ${ }^{\text {st }}$ ed., M. E. Sharpe, Inc., New Delhi. pp. 22-65.

8- Robbins, S. P. (2009). Organizational Behaviour Global and Southern Africa Perspectives. $2^{\text {nd }}$ ed., Pearson Education South Africa (Pty) Ltd., Cape town, p. 424.

9- Marcic, D. and Daft, R. L. (2011). Understanding Management. $7^{\text {th }}$ ed., SouthWestern Cengage Learning, Ohio, p. 59.

10- Kaila, H. L. (2005). Human resource management: second volume. $1^{\text {st }}$ ed., Kalpaz Publications, Delhi, p. 458.

11- El Hag, F. L. (2009). Impact of Organizational Culture on Success of Mergers and Acquisitions: an Analytical Study. Master dissertation, College of Education and Human Development, University of Louisville, p. 34, retrieved on December 23, 2012, from http://proquest.umi.com/pqdweb?did=1850906171\&sid=1\&Fmt=14\&VType=PQ D\&VInst $=$ PROD\&RQT $=309 \&$ VName $=$ PQD\&TS $=1356285483 \&$ clientId $=79356$

12-Robbins, S. P. (2005). Organizational Behavior. $11^{\text {th }}$ ed., Education Inc, upper saddle river, New Jersey, pp. 70- 485.

13-Flouris, T. G. and Oswald, S. L. (2006). Designing And Executing Strategy in Aviation Management. $1^{\text {st }}$ ed., Ashgate Publishing Limited, Hampshire, p. 7.

14- Lock, D. and Flouris, T. G. (2009). Managing Aviation Projects from Concept to Completion. $1^{\text {st }}$ ed., Ashgate Publishing Limited, Hampshire, p. 55.

15-Nelson, D. L. and, Quick, J.C. (2003). Organizational Behavior-Foundations, Realities, and Challenges. $4^{\text {th }}$ ed., South- Western, division of Thomson Learning, The Ohio State, pp. 116-132.

16- Woodall, J. (1996). Managing Culture Change: Can It Ever Be Ethical. Journal of Personnel Review, Vol. 25 (6), pp. 28-30.

17- Rokeach, M. (1973). The Nature of Human Values, $1^{\text {st }}$ ed., The Free Press, New York. 
18-Mullins, L. J. (2001). Hospitality Management and Organisational Behaviour. $4^{\text {th }}$ ed., British library cataloguing publication data, Malaysia, pp. 66-473.

19-Sims, R. R. (2002). Managing Organizational Behavior. $1^{\text {st }}$ ed., Quorum Books, Westport, p. 40.

20- Abdul Rashid, M. Z., Sambasivan, M. and Abdul Rahman, A. (2004). The Influence of Organizational Culture on Attitudes towards Organizational Change. Journal of the Leadership and Organizational Development, Vol.25 (2), pp. 161163.

21-Mullins, L. J. (2005). Hospitality Management and Organisational Behaviour. $5^{\text {th }}$ ed., Prentice Hall/Financial Times, London, pp. 83-84, 87.

22- Bryson, J. (2008). Dominant, Emergent, and Residual Culture: the Dynamics of Organizational Change. Journal of Organizational Change Management, Vol. 21 (6), pp. 743-745.

23-Shum, P., Bove, L., and Auh, S. (2008). Employees' Affective Commitment to Change. European Journal of Marketing, Vol. 42 (11, 12), pp. 1348- 1358.

24-Diefenbach, T. (2007). The Managerialistic Ideology of Organizational Change Management. Journal of Organizational Change Management, Vol.20 (1), pp. 127- 136.

25-Lines, R. (2011). The Structure and Function of Attitudes toward Organizational Change. Journal of Human Resource Development Review Vol. 4, (1), p. 16.

26- Falkenberg, J., Stensaker, I. G., Meyer, C. B., and Haueng, A. C. (2005). When Change Becomes Excessive. Journal of Organizational Change and Development, Vol. 15, pp. 31-62.

27-Kalyal, H. J., Berntson, E., Baraldi, S., Näswall, K. and Sverke, M. (2010). The Moderating Role of Employability on the Relationship between Job Insecurity and Commitment to Change. Journal of Economic and Industrial Democracy, Vol. 31(3), pp. 328-330.

28-Elias, S. M. (2009). Employee Commitment in Times of Change: Assessing the Importance of Attitudes toward Organizational Change. Journal of Management, Vol. 35(1), p.3.

29-Kimberley, N., and Hartel, C. E. J. (2007). Building a Climate of Trust during Organizational Change: the Mediating Role of Justice Perceptions and Emotion. Journal of Emotions in Organizations, Vol.3 pp. 237 - 264.

30-Bovey, W. H. and Hede, A. (2001). Resistance to Organizational Change: the Role of Defence Mechanisms. Journal of Managerial Psychology, Vol. 16(7), pp. 534-536.

31-Cameron, E. and, Green, M. (2009). Making Sense of Change Management: A Complete Guide to the Models Tools and Techniques of Organizational Change. $2^{\text {nd }}$ ed., Kogan Page Limited, London, pp. 32-261.

32- Val, M. P. and Feuntes, C. M. (2003). Resistance to Change: a Literature Review and Empirical Study. Journal of Management Decision, Vol. 41(2), pp. 148-155.

33- Parish, J. T., Cadwallader, S. and Busch, P. (2008). Want to, Need to, Ought to: Employee Commitment to Organizational Change. Journal of Organizational Change Management, Vol. 21 (1), pp. 33-36. 
34- Van den Heuvel, S., and Schalk, R. (2009). The Relationship between Fulfillment of the Psychological Contract and Resistance to Change during Organizational Transformation. Journal of Social Science Information, Vol.48 (2), pp. 283-313.

35-Gomez, A. M. and Crowther, D. (2012). Human Dignity and Managerial Responsibility: Diversity, Rights, and Sustainability. $1^{\text {st }}$ ed., Gower Publishing, Ltd. Surrey, p. 131.

36- Johns, G. and, Saks, A. M. (2005). Organizational Behaviour. 6th ed., Pearson Education Canada Inc., Toronto, pp.523-525.

37-Schermerhorn, J. R., Hunt, J. G. and, Osborn, R. N. (1997). Organizational Behavior. 6th ed., John Wiley \&Sons, Inc., New Jersey, pp. 400-404.

38- Wilkinson, A., Dale, B., and Cooper, C. (1997). Managing Quality and Human Resources. $1^{\text {st }}$ ed., Blackwell Publishers Inc. Oxford, pp. 177, 180, 181, 183.

39- Blomme, R. J., Tromp, D. M. and Rheede, A. V. (2008). Predictors of Turnover Intentions of Highly Educated Employees in the Hospitality Industry. Journal of Hospitality and Leisure, Vol. 4, pp. 3-28.

40- Reisel W. D., Chia S., Maloles C. M. and Slocum J. W., (2007). The Effects of Job Insecurity on Satisfaction and Perceived Organizational Performance. Journal of Leadership \& Organizational Studies Vol.14 (2) pp. 106-116.

41-Lund, D. B. (2003). Organizational Culture and Job Satisfaction. Journal of Business and Industrial Marketing, Vol.18 (3), pp. 219 - 236.

42-Noe, R. N., Hollenbeck, J. R., Gerhart, B. and, Right, P.M. (2000). Human Resource Management. 3rd ed., Library of Congress Cataloguing in Publication Data, The Ohio state, pp.77, 371, 439.

43- Byars, L. L. and, Rue, L.W. (2006). Human Resource Management. 8th ed., McGraw Hill companies, Inc., New York, p. 222.

44- Fiorentino, R., (2010). Performance Measurement in Strategic Changes. Journal of Managerial and Financial Accounting, Vol.20, pp. 253-283.

45-Cornelius, N. (2002). Building Workplace Equality: Ethics, Diversity and Inclusion. 1st ed., Thomson, London, p. 81.

46- Rafferty, A. E. and Restubog, S. L. (2010). The Impact of Change Process and Context on Change Reactions and Turnover during a Merger. Journal of Management, Vol. 36(5), pp. 1309-1338.

47-Fenton, E., and Pettigrew, A. (2006). Leading Change in the New Professional Service Firm: Characterizing Strategic Leadership in a Global Context. Journal of Sociology of Organization Vol. 24, pp. 101-137.

48-Tideswell, C., and Fredline, E. (2004). Developing and Rewarding Loyalty to Hotels. Journal of Hospitality and Tourism Research, Vol.28 (2), p. 186-208.

49-Berntson, E., Näswall, K. and Sverke, M. (2010). The Moderating Role of Employability in the Association between Job Insecurity and Exit, Voice, Loyalty and Neglect. Journal of Economic and Industrial Democracy, Vol. 31(2), pp. 215230. 
50- Bond, S., Hollywood, E. and Colgan, F. (2009). Integration in the workplace: emerging employment practice on age, sexual orientation and religion or belief. Research report 36, Equality and Human Rights Commission, pp. 71-72. retrieved on March 05, 2013, from http://www.equalityhumanrights.com/uploaded_files/research/integration_in_the workplace.pdf

51-Bogg, J. and Hussain, Z. (2010). Equality, diversity and career progression: Perceptions of radiographers working in the National Health Service. Journal of Radiography, Vol. 16 (4), pp. 262-267.

52-Trader-Leigh, K. E. (2002). Case Study: Identifying Resistance in Managing Change. Journal of Organizational Change Management, Vol.15 (2), pp. 138, 155.

53-Zhu, Y., May, S. K. and Rosenfeld L. B. (2004). Information Adequacy and Job Satisfaction during Merger and Acquisition. Journal of Management Communication Vol. 18 (2), pp. 241-270. 


\section{اثر تغيير الادارة على موظفي القنادق}

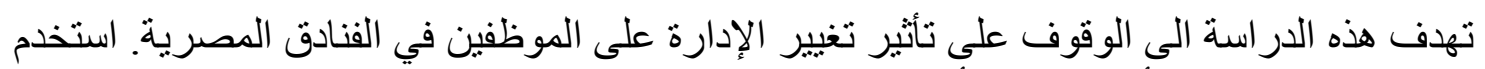

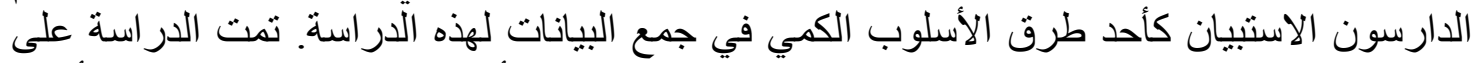

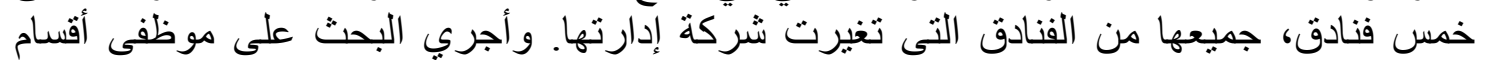

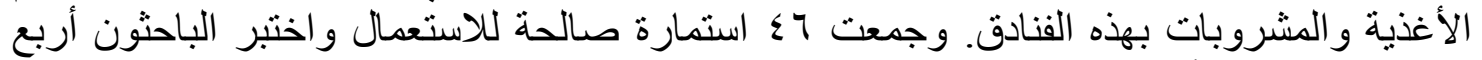

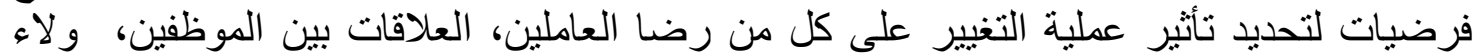

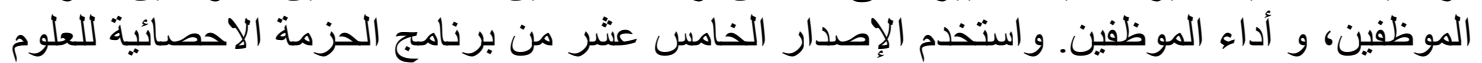

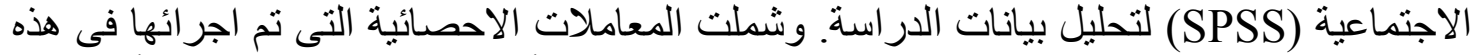

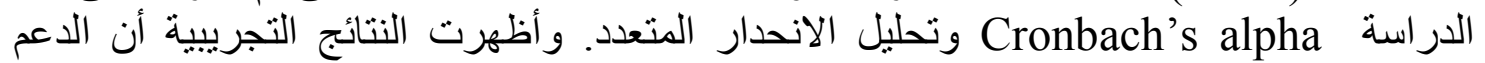

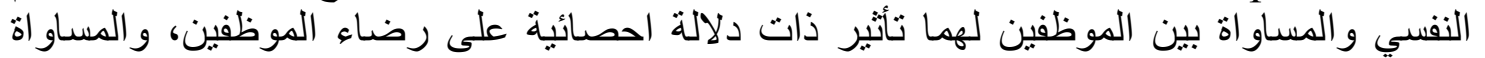

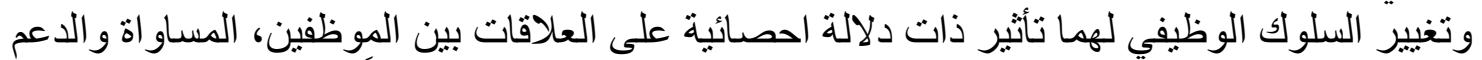

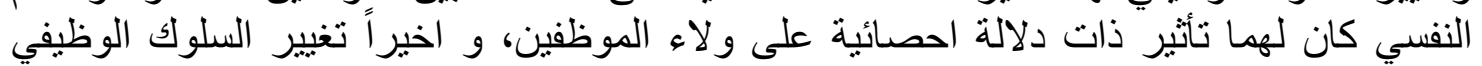
و المستّا اة بين الموظفين لهما تأثير ذات دلاتلة دالة احصائية على أداء الموظفين.

استناداً على الدراسات المرجعية، الدراسة الميدانية والنتائج أمكن التوصل إلى عدة توصيات وهى كالتالي:

ا ـ على الادارة الجديدة ان تأخذ فى اعتبار ها الاول العاملين لانهم اساس نجاح الفندق او فثلها، وان تر اعى الاختلافات الثقافية بين العاملين.

rـ اشتر اك العاملين فى عملية اتخاذ القرار من الامور الضرورية بجانب اتباع احد الاساليب

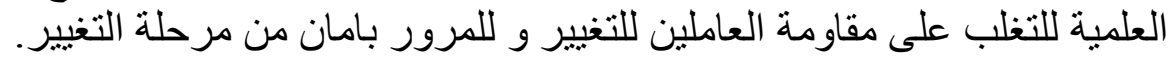

r- من من الافضل للادارة الجديدة ان تكسب ثقة العاملين وخلق جو من الالفة بينها وبين العاملين من ناحية وبين العاملين بعضهم البعض من ناحية اخرى.

ــ ـ على الادارة الجديدة ان تجعل العاملين يشعرون بالامان الوظيفى و العدالة جر اء هذا التغيير

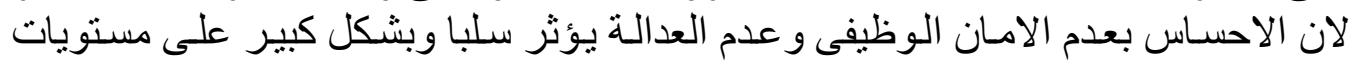

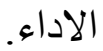
هـ ينبغى تنظيم الادارة الجديدة بر امجاً لنشر أساليبها الادارية بين العاملين بالفندق. 